\title{
TU/e EmonOWEN

\section{Investigation of parameters affecting the supercritical fluid extraction of polymer additives from polyethylene}

\section{Citation for published version (APA):}

Lou, X. W., Janssen, J. G. M., \& Cramers, C. A. M. G. (1995). Investigation of parameters affecting the supercritical fluid extraction of polymer additives from polyethylene. Journal of Microcolumn Separations, 7(4), 303-318. https://doi.org/10.1002/mcs.1220070403

DOI:

10.1002/mcs. 1220070403

Document status and date:

Published: 01/01/1995

\section{Document Version:}

Publisher's PDF, also known as Version of Record (includes final page, issue and volume numbers)

\section{Please check the document version of this publication:}

- A submitted manuscript is the version of the article upon submission and before peer-review. There can be important differences between the submitted version and the official published version of record. People interested in the research are advised to contact the author for the final version of the publication, or visit the $\mathrm{DOI}$ to the publisher's website.

- The final author version and the galley proof are versions of the publication after peer review.

- The final published version features the final layout of the paper including the volume, issue and page numbers.

Link to publication

\section{General rights}

Copyright and moral rights for the publications made accessible in the public portal are retained by the authors and/or other copyright owners and it is a condition of accessing publications that users recognise and abide by the legal requirements associated with these rights.

- Users may download and print one copy of any publication from the public portal for the purpose of private study or research.

- You may not further distribute the material or use it for any profit-making activity or commercial gain

- You may freely distribute the URL identifying the publication in the public portal.

If the publication is distributed under the terms of Article 25fa of the Dutch Copyright Act, indicated by the "Taverne" license above, please follow below link for the End User Agreement:

www.tue.nl/taverne

Take down policy

If you believe that this document breaches copyright please contact us at:

openaccess@tue.nl

providing details and we will investigate your claim. 


\title{
Investigation of Parameters Affecting the Supercritical Fluid Extraction of Polymer Additives from Polyethylene
}

\author{
Xianwen Lou, Hans-Gerd Janssen, ${ }^{*}$ and Carel A. Cramers \\ Eindhoven University of Technology, Laboratory of Instrumental Analysis, \\ P.O. Box 513, 5600 MB Eindhoven, The Netherlands
}

\begin{abstract}
Polymer additives were extracted from polyethylene with supercritical carbon dioxide. The two-film theory, which considers mass transfer across a phase boundary, is applied to qualitatively describe the kinetics of mass transfer from the core of the polymer particles into the supercritical fluid extractant. The effects of pressure, temperature, addition of benzene as a modifier, properties and concentrations of the solutes, static time, and supercritical fluid extractant flow rate on the extraction process are investigated systematically. At constant temperature the extraction rates first increase with increasing pressure. When pressure reaches a certain level, a further increase of the pressure does not further increase the extraction rates. At constant pressure, the extraction rates were found to increase first and then decrease with increasing temperature. In addition to pressure and temperature, the SFE extraction kinetics is also influenced by the solute concentration, and the rate-limiting parameter in the extraction can be changed from solubility to diffusion during the course of the extraction. The magnitude of the effects of the experimental parameters depends on the properties and molecular weights of the solutes. The role of benzene as a modifier in the extraction of polymer additives from polyethylene is swelling the polymer particles and improvement of the solvent strength of the supercritical fluid extractant. Modifier effects were found to be more pronounced at lower temperatures. (c) 1995 John Wiley \& Sons, Inc.
\end{abstract}

Key words: supercritical fluid extraction (SFE), polymers, polymer additives, extraction kinetics

\section{INTRODUCTION}

Polymers are widely used materials and are indispensible to mankind nowadays, being essential to clothing, shelter, transportation, and communication, as well as to the convenience of modern living [1]. Their properties can be improved by the presence of appropriately selected additives. Hitherto, Soxhlet extraction is normally used to determine the contents of polymer additives. However, this method is both time and solvent consuming. Additionally, after extraction the samples have to be concentrated and there is a requirement to dispose of the organic solvent in an appropriate manner. Recent concern about the hazards associated with most of the solvents used, the cost and the environmental dangers of waste solvent disposal, have led to the development of alternative sample extraction methods [2].

Supercritical fluid extraction (SFE) has many advantages over Soxhlet extraction. Besides advantages such as a reduced usage of organic solvent, shorter extraction time, adjustable solvent strength, and the ability for on-line combination with analytical instruments [3-5], the extraction temperature in SFE can be changed continuously from the critical point of the supercritical fluid to temperatures well above the glass transition temperature of a polymeric material. This is in contrast to

* To whom all correspondence should be addressed. 
Soxhlet extraction where the extraction temperature is limited by the boiling point of the extraction solvent used. The wide range of extraction temperatures available in SFE is of particular importance. For example, the low critical temperature of supercritical carbon dioxide makes SFE an excellent candidate for extracting thermally labile compounds under conditions slightly above room temperature [6]. The high extraction temperatures available, on the other hand, favorably affect the diffusion coefficients of the compounds and thus increase the SFE extraction rate for samples in which the rate-limiting parameter is related to diffusion in the matrix, such as in the case of extracting polymer additives from polymeric materials [7].

SFE has been applied successfully to a wide variety of matrix/analyte combinations [8]. In the extraction of polymer additives from polymeric materials, the SFE process normally involves three steps. First, the solutes have to diffuse from the core of the polymeric material to the surface. Next, the compounds are transferred from the surface into the extraction fluid. Finally, the compounds are eluted out of the extraction cell by the flow of the supercritical extractant. Up till now, only a limited number of fundamental studies were carried out that aimed at increasing the knowledge of the various experimental parameters that affect the extraction behavior in the SFE extraction of polymeric materials. Bartle et al. [9] derived a model for diffusion-limited extractions assuming that the matrix particles are spheres of a well-defined size and the initial distribution of the solutes within the spheres is uniform. Cotton et al. [10] and Kueppers [11] investigated temperature effects in SFE and found that higher extraction efficiencies could be obtained at elevated temperatures. Venema et al. [12] studied the effects of particle size on the SFE extraction efficiency in the extraction of caprolactam and oligomers from nylon-6. Expectedly, higher extraction rates were observed for smaller particles. In each of the four studies referred to above, pressure and temperature conditions were such that the rate-limiting factor for extraction was diffusion of the solutes in the polymeric materials. However, the actual mechanism that governs the extraction of compounds from polymeric materials is far more complicated. Diffusion in the matrix particles is of course important, but other parameters such as solubility of the components in the supercrit- ical extractant can also play an important role. Parameters affecting any one of the three subsequent steps in SFE identified above will influence the ultimate SFE efficiency.

In this article, the effects of various operational parameters such as temperature, pressure, supercritical fluid flow rate, static time, modifier concentration, and solute characteristics on the SFE kinetics in the extraction of polymer additives from polyethylene were investigated. Attempts are made to identify the rate-determining step in the SFE process for the various sets of experimental conditions evaluated. The role of the modifier in the extraction of polymeric materials is also investigated and discussed.

\section{THEORY}

In the SFE extraction of polymer materials, the solutes are extracted from the core of the polymer particles into the supercritical fluid. The kinetics of mass transfer in this process can be represented by the two-film theory as is illustrated in Figure 1 [13]. The basis of this theory is the assumption that the zones in which the resistance to mass transfer lies can be replaced by two hypothetical layers, one on each side of the polymer surface. In these layers mass transfer is entirely by molecular diffusion. The concentration gradient is therefore linear in each of these layers and zero outside. The relative positions of the points $C$ and $D$ in Figure 1 are determined by the equilibrium distribution between the two phases. The twofilm theory describes the general process occurring when a solute is transferred from one

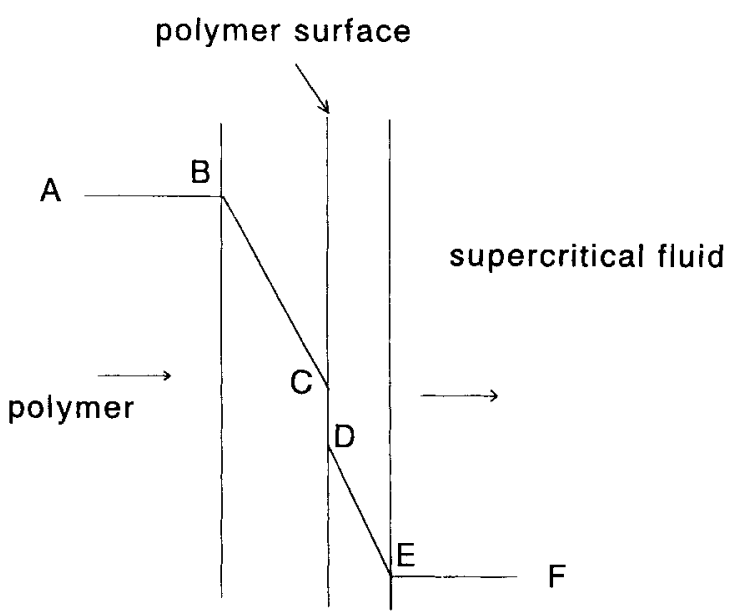

Figure 1. Schematic representation of the twofilm theory. 
phase to another. In SFE, mass transfer from the core of the polymer particles to the surface is controlled by molecular diffusion. Here the diffusion coefficient is determined by parameters such as properties and structures of the polymeric material and the solutes, extraction temperature, presence of a modifier etc. In general this step is slow because diffusion in the polymer particles is slow. Mass transfer from the polymer surface through the stagnant layer outside the polymer particles into the supercritical fluid stream, on the other hand, is extremely fast because supercritical fluids have high solute diffusivities. Moreover, the layer of stagnant extraction fluid around the particles is very thin. After being transferred into the supercritical fluid stream, the components are eluted out of the extraction cell by the flow of the extractant. The elution rate here is determined by the solubilities of the components and the flow rate of the supercritical fluid. From the discussions presented above, it is clear that the SFE process can be modelled as three subsequent steps. First, the solutes must diffuse from the core of the polymeric material to the surface. Next the solutes should be transferred from the surface into the supercritical fluid stream. Finally the solutes are eluted out of the extraction cell. The SFE extraction rate is limited by the slowest of these three steps. As explained above, mass transfer from the surface of the polymer particles into the supercritical fluid extractant is very fast. Hence, the slowest, and therefore the rate-limiting step, is either diffusion in the particle or elution out of the extraction cell. The two possible extremes concerning the rate-limiting step are schematically shown in Figure 2.

In Figure $2 \mathrm{~A}$, the situation is depicted in which the rate-limiting step is diffusion of the solute in the polymer matrix. Increasing the diffusion coefficient of the solute by, for example, increasing the extraction temperature will increase the extraction rate. If the rate-limiting step is elution of the components out of the extraction cell (Figure 2B), enhanced extraction rates can be obtained either by increasing the solvent strength of the extractant (i.e., by increasing the extraction pressure or by the addition of a modifier), or by increasing the supercritical fluid flow rate.

As discussed above, many experimental parameters affect the kinetics of SFE extraction. Among these, temperature, pressure, and type and concentration of a modifier appear to be the most important ones. At low temperatures and high pressures (high densities), the solubility of the components in the extraction fluid is high but diffusion of the solutes in the polymeric material is slow. The extraction rate is now limited by diffusion inside the polymer particles. In contrast to this, at high temperatures and low pressures (low densities), diffusion of the solutes in the polymeric material is fast, while the solubility of the compounds in the supercritical fluid is low and solubility becomes the rate-limiting parameter. When a modifier is used, the SFE mechanism becomes even more complicated as the modifier can affect both the matrix properties (swelling and deactivation) as well as the fluid phase properties (polarity and density).

\section{EXPERIMENTAL}

SFE experiments were performed with a modified Carlo Erba SFC 3000 capillary SFC instrument (Carlo Erba, Milan, Italy). A $3 \mathrm{~mL}$ stainless steel extraction cell (Suprex, Pittsburgh, PA) was fitted with hand-tight connectors (Suprex, Pittsburgh, PA) for easy installation. Stainless steel frits $(3 \mu \mathrm{m})$ were located at either end of the extraction cell. Fused-silica capillaries $(20 \mu \mathrm{m}$ i.d. or $50 \mu \mathrm{m}$ i.d. with a length of $50 \mathrm{~cm}$ ) were used as restrictors. To enable static extraction an on-off valve (Valco, Switzerland) was installed directly behind the extraction cell. The extracted material was collected by inserting the restrictor outlet into a

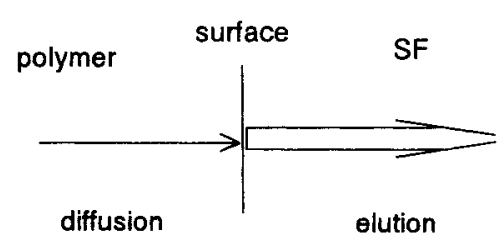

A

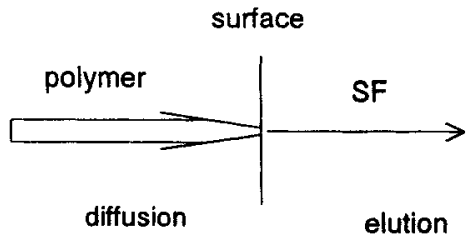

B

Figure 2. Schematic diagram of two possible extremes concerning the rate-limiting step in SFE. 
glass vial $(10 \mathrm{~cm} \times 1 \mathrm{~cm}$ i.d. $)$ containing $5 \mathrm{~mL}$ dichloromethane. This vial was changed every $30 \mathrm{~min}$. Tetracontane was added to each vial as an internal standard. After collection, dichloromethane was evaporated under a gentle flow of nitrogen and the extracted material was redissolved in a suitable amount of hexane.

The polyethylene sample (powder) was obtained from DSM (Geleen, The Netherlands). The glass transition temperature of the polymer (under nonswollen conditions) is approximately $-20^{\circ} \mathrm{C}$. About $0.8 \mathrm{~g}$ polyethylene was weighed into the extraction cell before extraction. A static time of $30 \mathrm{~min}$ was used prior to dynamic extraction unless stated otherwise. The highest extraction temperature tested in the experiments was $80^{\circ} \mathrm{C}$. At higher temperatures the restrictor often blocked due to partial melting of the polymer. In the experiments with modifier, benzene was added directly to the extraction cell prior to extraction. The carbon dioxide used in the experiments had a purity of $99.996 \%$ (Intermar B.V. Breda, The Netherlands). Soxhlet extraction was performed to produce a frame of reference. SFE extraction efficiencies were calculated relative to the Soxhlet data. For Soxhlet extraction, about $2 \mathrm{~g}$ sample was placed in the Soxhlet extractor and extracted with hexane for 36 hours.

The extracted components were analyzed using a gas chromatograph equipped with an on-column injector and an FID (GC 8000 series, Carlo Erba Instruments). The gas chromatographic separation was achieved with a
HT-SIMDIST CB column $(10 \mathrm{~m} \times 0.53 \mathrm{~mm}$ i.d., film thickness $0.17 \mu \mathrm{m}$ ) purchased from Chrompack (Middelburg, The Netherlands). The initial temperature for $\mathrm{GC}$ separation was $40^{\circ} \mathrm{C}$. The temperature was then programmed to $425^{\circ} \mathrm{C}$ at $20^{\circ} \mathrm{C} / \mathrm{min}$.

\section{RESULTS AND DISCUSSION}

Effects of pressure. The extraction kinetics in SFE are determined by a number of experimental parameters. The fact that these parameters are generally interrelated is an additional complicating factor in method development in SFE. Figures 3 and 4 illustrate the influence of the extraction pressure on the extraction yields of three polymer additives, Irgafos 168, Irganox 1076 , and Irganox 1010, from polyethylene at temperatures of $50^{\circ} \mathrm{C}$ and $80^{\circ} \mathrm{C}$, respectively. From these figures it is clear that the effect of pressure changes can be different at different temperatures. When pressure is increased from 150 to 300 bar at $50^{\circ} \mathrm{C}$, no significant variation in the extraction yields of the three additives is observed (Figure 3). This is because at $50^{\circ} \mathrm{C}$ the density of the supercritical fluid is relatively high, even at a mild pressure of only 150 bar $(\rho=0.701 \mathrm{~g} / \mathrm{mL})$. As the diffusion coefficients of the components in the polymer are relatively small, the mass flow of components diffusing to the polymer surface is low. Molecules diffused to the surface are rapidly removed from the surface of the polymer particles and are rapidly carried out of the extraction cell by the flow of high density carbon dioxide. Under these condi-

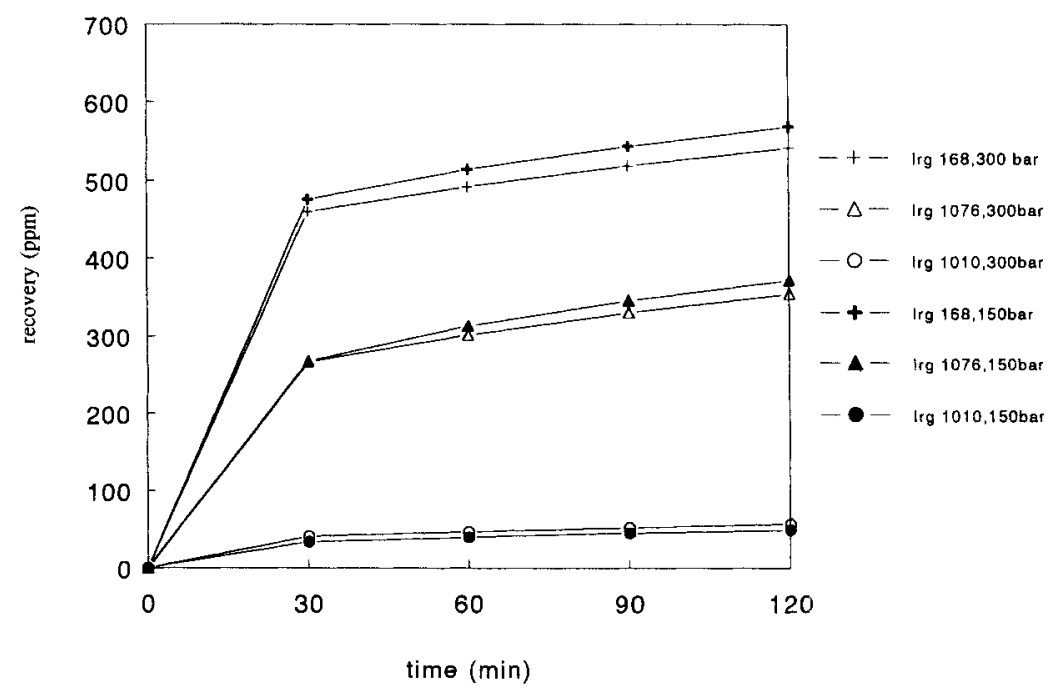

Figure 3. Effects of pressure on $S F E$ extraction rate at $50^{\circ} \mathrm{C}$ : static time, $30 \mathrm{~min}$; restrictor, $50 \mathrm{~cm} * 50$ $\mu \mathrm{m}$ fused-silica capillary; collection solvent, $5 \mathrm{~mL}$ dichloromethane. 


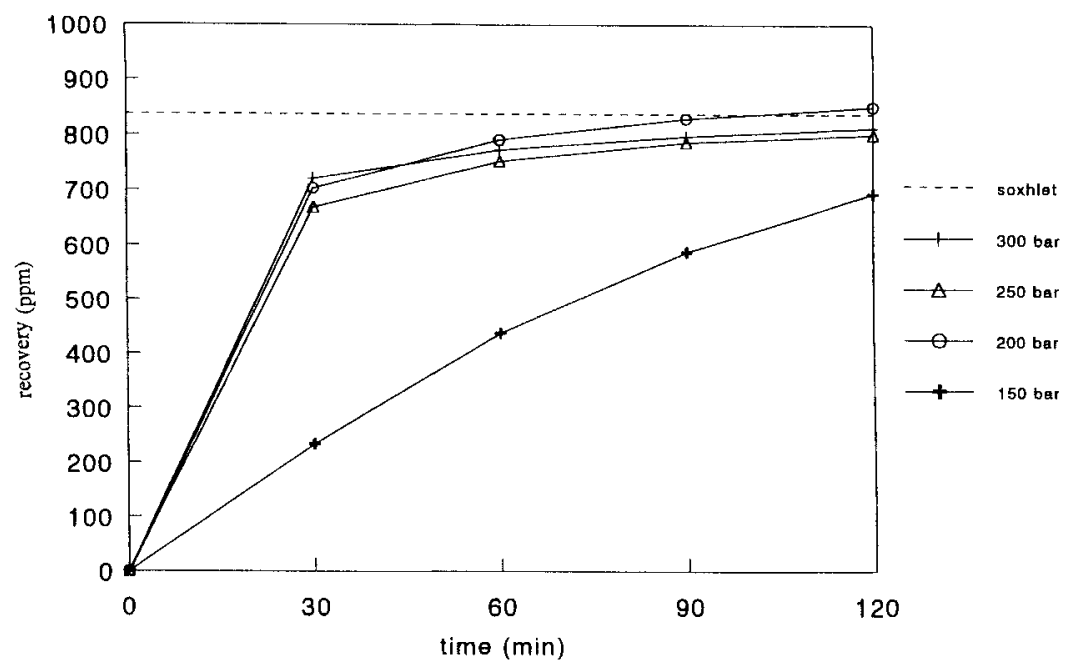

(a)

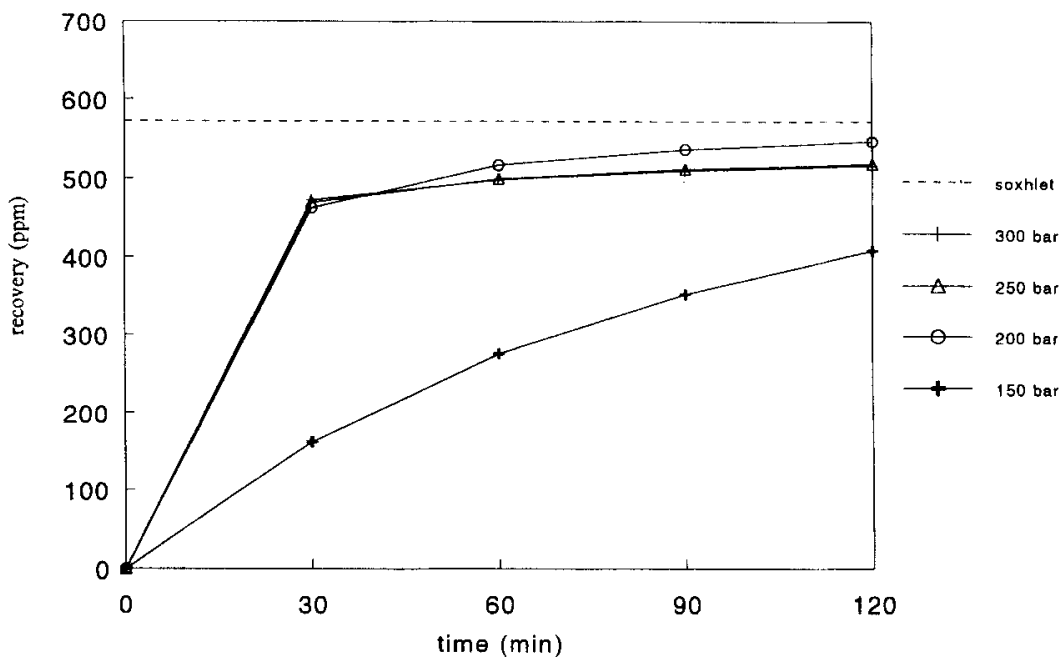

(b)

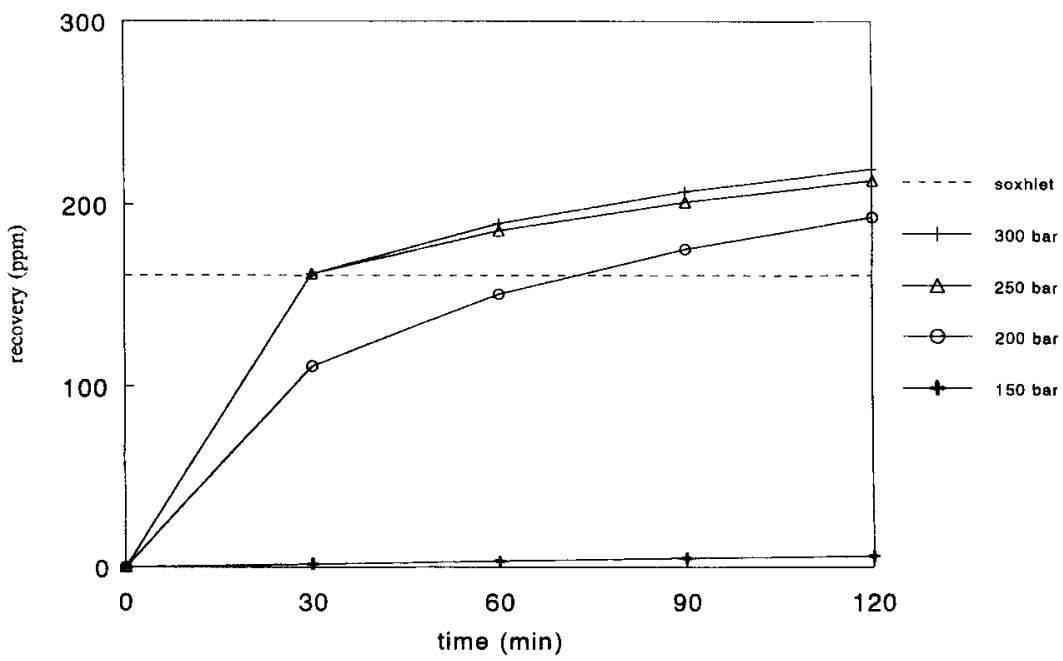

(c)

Figure 4. Effects of pressure on SFE extraction rate at $80^{\circ} \mathrm{C}$ : A: Irgafos 168; B: Irganox 1076; C: Irganox 1010. Other details as in Figure 3. 
tions, the solubility of the components in the supercritical fluid is clearly not the rate-limiting parameter. The extraction rate is determined by diffusion of the additives in the polymer matrix. A different situation occurs at a temperature of $80^{\circ} \mathrm{C}$ (Figure 4). Increasing the pressure from 150 to 200 bar at $80^{\circ} \mathrm{C}$ increases the extraction rates drastically for Irgafos 168 and Irganox 1076, especially in the first fraction of $30 \mathrm{~min}$. A further increase of the pressure from 200 to 300 bar, however, gives no further improvement in extraction yields for these two components (Figures $4 \mathrm{a}$ and $\mathrm{b}$ ). The effects of pressure on the extraction rate of Irganox 1010 are even more pronounced than those observed for Irgafos 168 and Irganox 1076 (Figure 4c). Almost no extraction occurs for Irganox 1010 at $80^{\circ} \mathrm{C}$ and pressures below 150 bar. Increasing the pressure from 150 to 200 bar causes the extraction rate of this solute to increase significantly. An additional, but smaller increase in extraction rate is observed if the pressure is increased from 200 to 250 bar. At these conditions the extraction yield even exceeds that of Soxhlet extraction. No further increase in the extraction rate is observed upon further increasing the pressure from 250 to 300 bar. Summarizing, at a constant temperature, the extraction rate first increases with increasing pressure. After the pressure reaches a certain level, further increasing of the pressure does not result in a further increase of the extraction rate. Apparently above a certain pressure value, the solubility of the components on the supercritical fluid is no longer the rate-limiting parameter for extraction. The extraction rate is now limited by the rate of diffusion of the solutes in the polymer particles.

Effects of temperature. The effects of temperature at constant pressure are even more complicated than the effects of pressure at constant temperature described above. Increasing the temperature increases the diffusion coefficients of the solutes in the polymer, whereas at the same time it also decreases the density and, related to this, the solvent strength of the supercritical fluid. If the pressure is sufficiently high, the supercritical fluid is capable of rapidly dissolving the components diffused to the surface, which means that the solubility of the component in the supercritical fluid is not the rate-limiting parameter for extraction. Increasing the temperature will speed up diffusion of the solutes in the polymeric material, thereby increasing the extraction rate. Opposedly, how- ever, if the pressure is too low, i.e., the solubility of the components in the supercritical fluid is limited, an increase in temperature will further decrease the density and the solvent strength of the supercritical fluid thereby reducing the extraction rate of the nonvolatile polymer additives in spite of the increase in the diffusion coefficients. For the polyethylene sample, the extraction efficiency at 300 bar increased considerably for each of the three additives when the temperature was raised from 50 to $80^{\circ} \mathrm{C}$ (Figure 5). Apparently, under these conditions the density of the supercritical fluid is relatively high and the extraction rate is determined by diffusion of the solutes from the core of the polymer particles to the surface. At a lower pressure of 150 bar, the amount extracted in the first $30 \mathrm{~min}$ first increased and then decreased with increasing temperature (Figure 6). At the highest temperature studied $\left(80^{\circ} \mathrm{C}\right)$ almost no Irganox 1010 was extracted. Under these low density conditions the supercritical carbon dioxide is apparently not capable of dissolving the molecules diffused to the surface. It is interesting to see that both for Irgafos 168 and Irganox 1076, the recoveries in the first fraction of $30 \mathrm{~min}$ at $150 \mathrm{bar}$ and $80^{\circ} \mathrm{C}$ are lower than those obtained at 150 bar and $50^{\circ} \mathrm{C}$, whereas, at prolonged extraction times the yields approach and finally exceed the recoveries at $50^{\circ} \mathrm{C}$. Most likely, during the first fraction of $30 \mathrm{~min}$, the concentrations of the solutes on the surface of the polymer particles are relatively high, whereas their solubility in the supercritical fluid is limited. As the extraction proceeds, the components are continuously transported out of the extraction cell by the flow of the supercritical fluid and their concentrations gradually decrease. At lower concentrations the solubilities of the components in the supercritical fluid are no longer limiting factors and diffusion in the polymer now becomes important. From this it is clear that the rate-limiting parameter is also related to solute concentration. In practical extractions, it is very well possible that the rate-limiting parameter changes from solubility to diffusion during the course of the extraction process.

Effects of solute molecular properties. From the preceding paragraphs it can be seen that the actual influence of temperature and pressure on the extraction yield versus time curve can depend on the properties of the additives to be extracted. To investigate the influence of the molecular structure on the extraction behavior, 


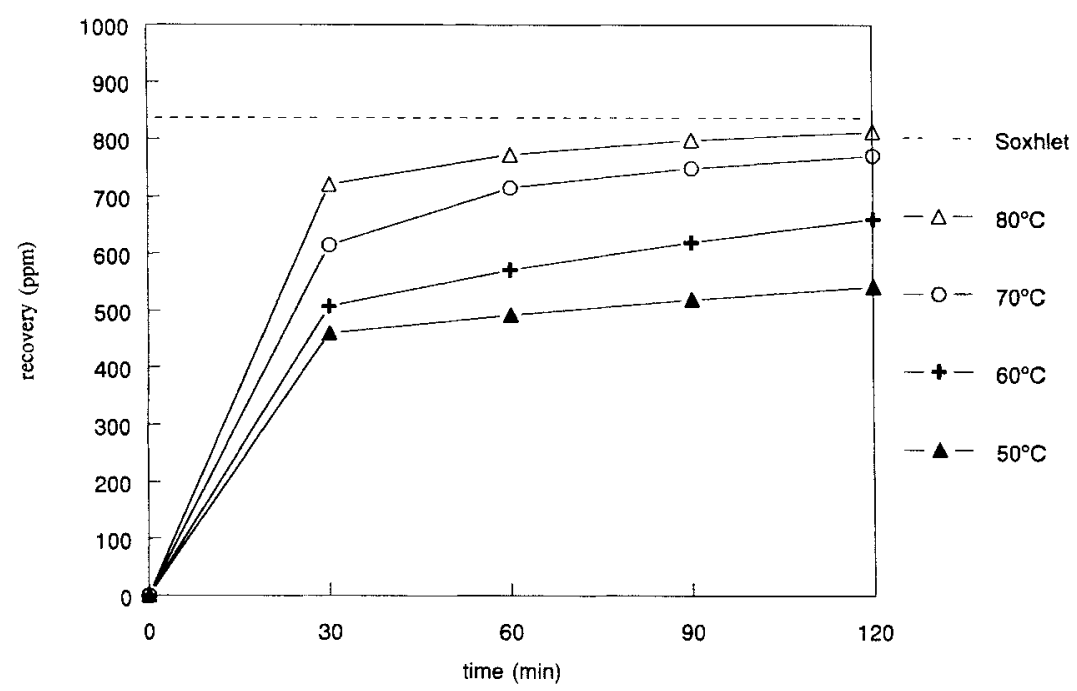

(a)

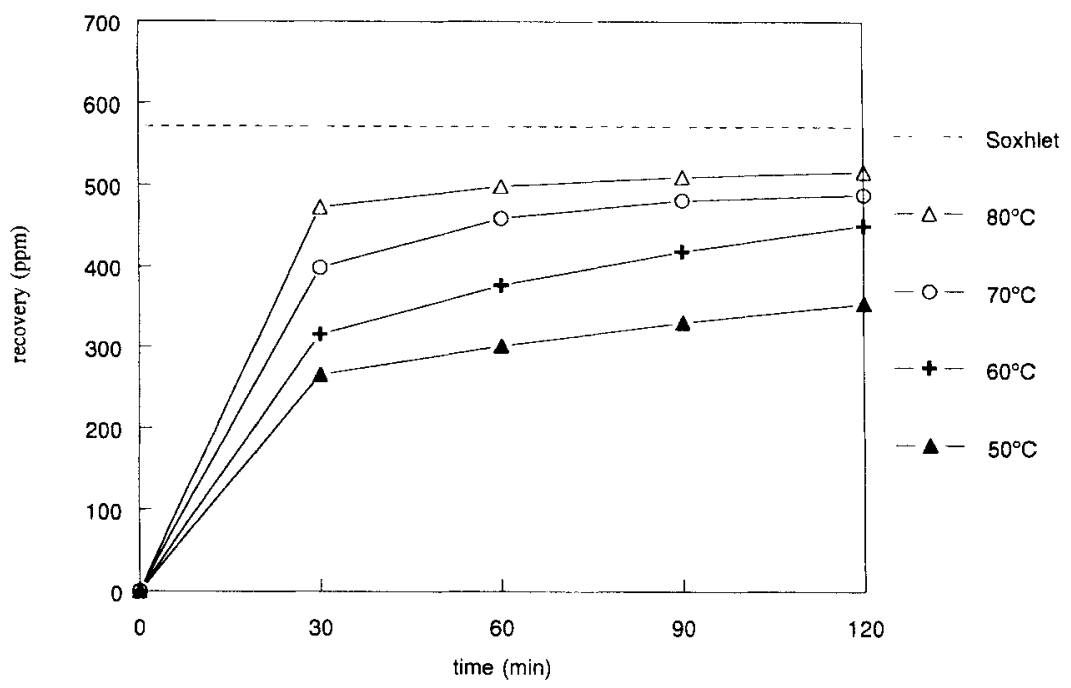

(b)

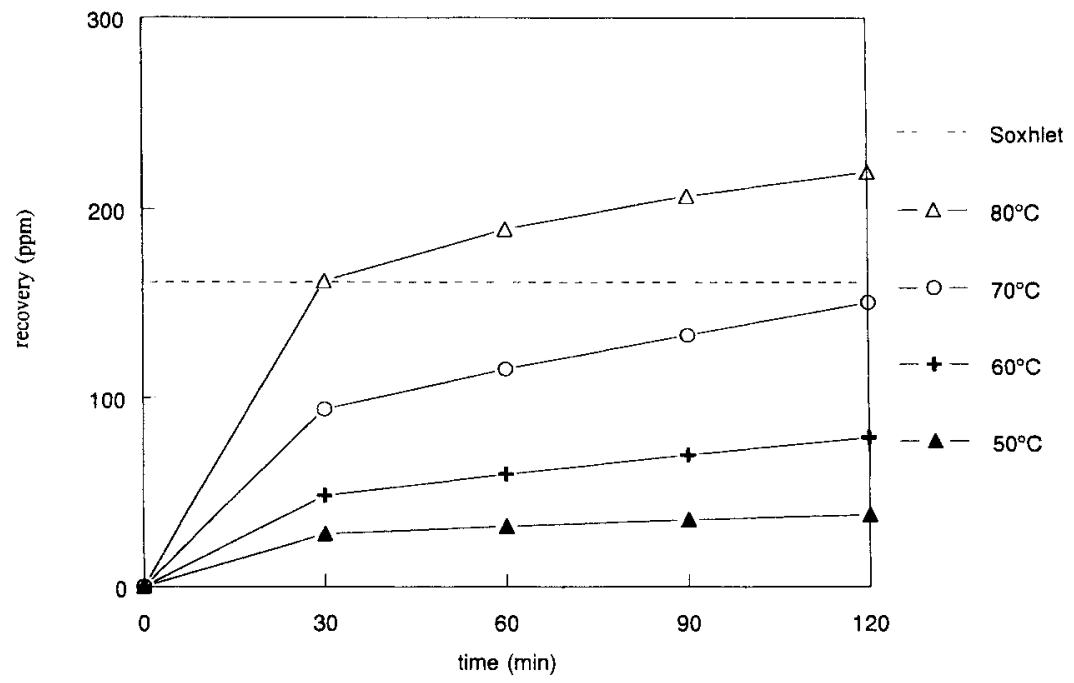

(c)

Figure 5. Effects of temperature on SFE extraction rate at 300 bar. A: Irgafos 168; B: Irganox 1076; C: Irganox 1010. Other details as in Figure 3. 


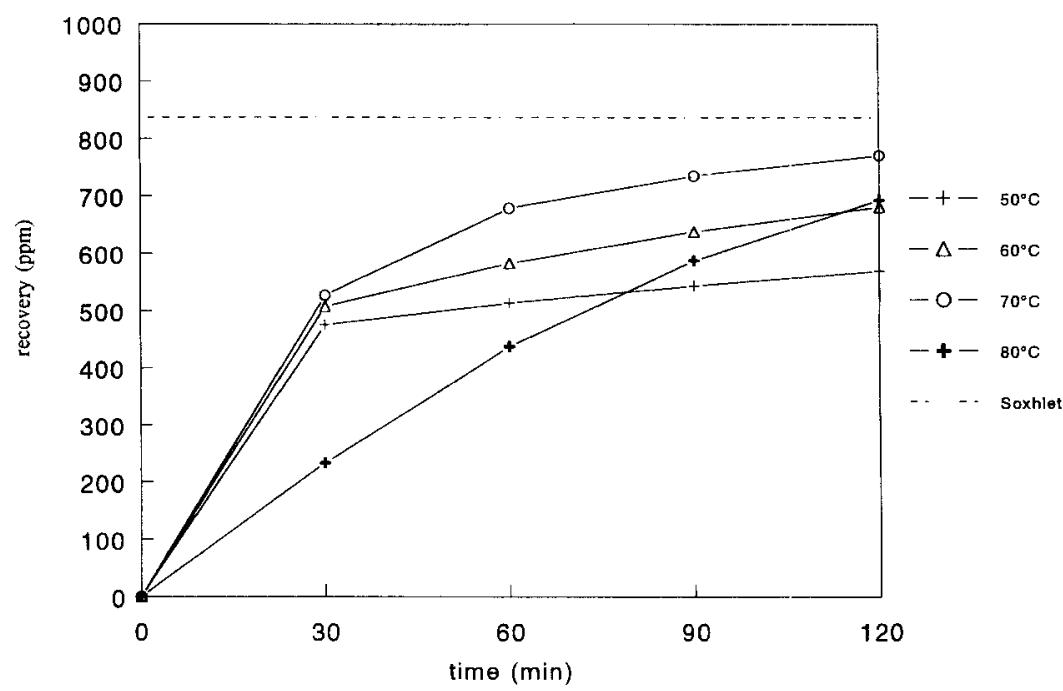

(a)

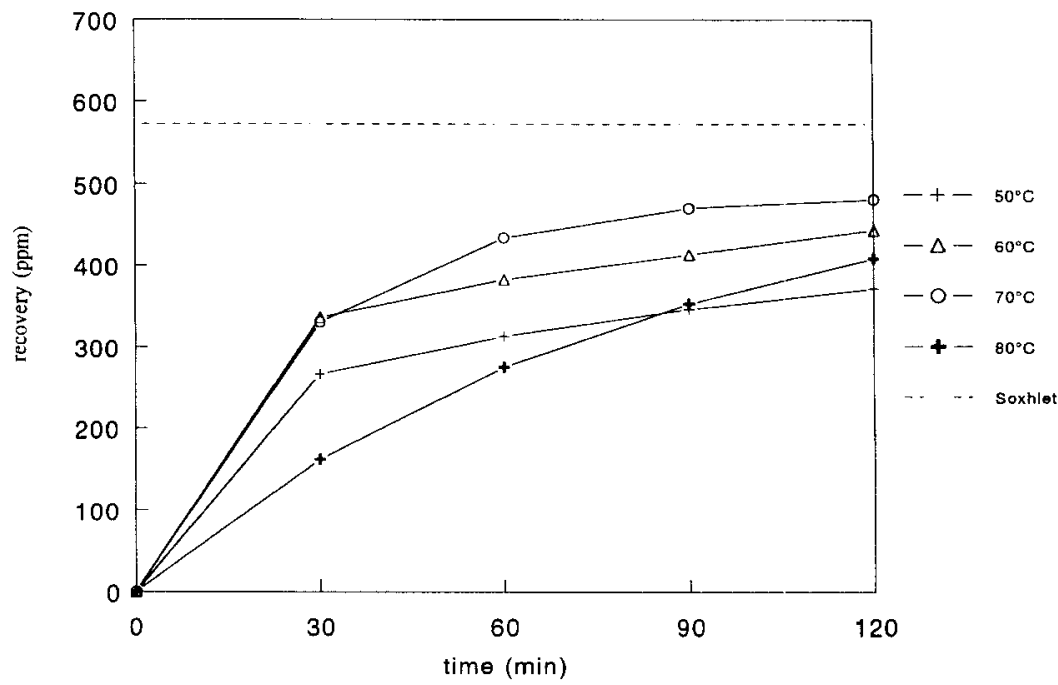

(b)

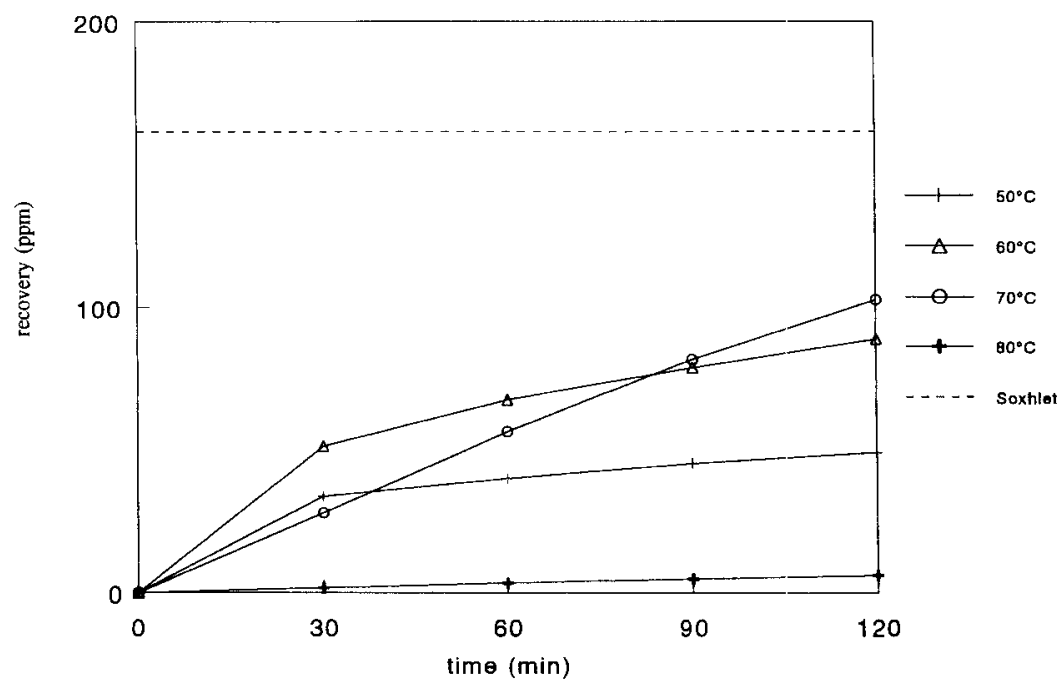

(c)

Figure 6. Effects of temperature on SFE extraction rate at 150 bar. A: Irgafos 168; B: Irganox 1076; C: Irganox 1010. Other details as in Figure 3. 
the amounts extracted for the various additives in the first fraction of 30 min were studied. In order to allow a direct comparison, the amounts extracted were expressed relative to the amounts found in the Soxhlet extraction. The results are listed in Tables I and II. Under conditions where the rate-limiting parameter is diffusion of the solutes in the polymer, e.g., 300 bar and temperatures between 50 and $80^{\circ} \mathrm{C}$, the amounts extracted in the first $30 \mathrm{~min}$ increase with temperature. The increases for Irgafos 168 and Irganox 1076 are of the same magnitude, whereas a more pronounced increase is found for Irganox 1010 (Table I). Most likely, this difference is due to differences in the molecular structures or weights of the additives. It is remarkable to see that Irganox 1010, $30 \mathrm{~min}$ SFE extraction at $80^{\circ} \mathrm{C}$ and 300 bar gives a slightly better extraction yield than $36 \mathrm{~h}$ of Soxhlet extraction. The molecular sizes of Irgafos 168 (relative molecular mass 647) and Irganox 1076 (relative molecular mass 537) are similar, whereas Irganox 1010 (relative molecular mass 1178) is clearly larger. Therefore, migration of Irganox 1010 in the polymer is restricted and the activation energy for diffusion will be higher. The activation energies for diffusion of Irgafos 168 and Irganox 1076, on the other hand, are of a similar magnitude. The variation of diffusion coefficient with temperature is generally described by an Arrhenius-type equation [14]:

$$
\mathrm{D}_{\mathrm{T}}=\mathrm{D}_{0} \exp \left(-\frac{\mathrm{E}}{\mathrm{RT}}\right)
$$

where $\mathrm{D}_{\mathrm{T}}$ is the diffusion coefficient at temperature $\mathrm{T}, \mathrm{D}_{0}$ is a constant related to the entropy of activation, and $E$ is the activation energy. From this equation, it can be seen that the diffusion coefficients increase with increasing temperature. This effect is more pronounced for components with a higher activation energy (larger molecules). Additionally, the apparent activation energy for diffusion decreases with increasing temperature as the activation energy is related to the amount of energy required to form transient voids in the matrix [15].

Changes in temperature affect the extraction process in two opposite ways. An increase in temperature will, on the one hand, increase the diffusion of solutes inside the polymeric material and, on the other, decrease the density or solvent strength of the extractant. Because large molecules are generally less soluble in supercritical carbon dioxide than smaller molecules, the density decrease at increased temperature is more likely to become a problem for the heavier solutes. This is confirmed by the experimental results. At 150 bar, the reduction in the recovery of Irganox 1010 at increased temperatures is more severe than that of Irgafos 168 or Irganox 1076. From this it is clear that in SFE the recoveries of larger molecular weight solutes are more sensitive to temperature and pressure.

Effects of supercritical fluid flow rate. In the experiments described above, the restrictor used was a piece of $50 \mathrm{~cm} \times 50 \mu \mathrm{m}$ fused-silica capillary. In order to investigate the effects of the supercritical fluid flow rate on the SFE kinetics, the restrictor was replaced by a $20 \mu \mathrm{m}$ fused-silica capillary with the same length. The supercritical fluid flow rate with the $50 \mu \mathrm{m}$ capillary was approximately five times higher than that with the $20 \mu \mathrm{m}$ restrictor. As far as the extraction yields were concerned, no significant differences between these two restrictors were observed for the three additives at 300 bar and $50^{\circ} \mathrm{C}$. When the same experiments were repeated at 300 bar and $80^{\circ} \mathrm{C}$, the amounts of Irgafos 168 and Irganox 1076 extracted in the first $30 \mathrm{~min}$ at lower flow rates were reduced considerably in comparison with that obtained at the higher flow rate. Opposed to this, under these conditions the extraction rate for Irganox

Table I. Comparison of effects of temperature on the SFE extraction recoveries of different additives in the first 30 min fraction at 300 bar. $^{a}$

\begin{tabular}{cccc}
\hline Temp $\left({ }^{\circ} \mathrm{C}\right)$ & $\begin{array}{c}\text { Irgafos } 168 \\
(\%)\end{array}$ & $\begin{array}{c}\text { Irganox 1076 } \\
(\%)\end{array}$ & $\begin{array}{c}\text { Irganox } 1010 \\
(\%)\end{array}$ \\
\hline 50 & 54.9 & 46.4 & 21.2 \\
60 & 60.6 & 55.2 & 29.6 \\
70 & 73.4 & 69.7 & 58.2 \\
80 & 86.1 & 82.5 & 100.4 \\
\hline
\end{tabular}

\footnotetext{
${ }^{\mathrm{a}} \mathrm{SFE}$ extraction recoveries were calculated relative to Soxhlet data.
} 
Table II. Comparison of effects of temperature on the SFE extraction recoveries of different additives in the first 30 min fraction at $150 \mathrm{bar}^{a}$

\begin{tabular}{cccc}
\hline Temp $\left({ }^{\circ} \mathrm{C}\right)$ & $\begin{array}{c}\text { Irgafos } 168 \\
(\%)\end{array}$ & $\begin{array}{c}\text { Irganox } 1076 \\
(\%)\end{array}$ & $\begin{array}{c}\text { Irganox } 1010 \\
(\%)\end{array}$ \\
\hline 50 & 56.8 & 46.6 & 20.8 \\
60 & 60.6 & 58.9 & 31.7 \\
70 & 63.0 & 57.7 & 17.2 \\
80 & 27.9 & 28.3 & 1.0 \\
\hline
\end{tabular}

${ }^{a}$ SFE extraction recoveries were calculated relative to Soxhlet data.

1010 did not change noticeably when the restrictor was replaced (Table III). At prolonged extraction times, the difference in extraction yields of Irgafos 168 and Irganox 1076 between these two restrictors also disappeared. The explanation for these observations is that at $50^{\circ} \mathrm{C}$ diffusion of the solutes in the polymer is relatively slow, whereas the density of the supercritical fluid is fairly high. Components diffused to the surface can be easily dissolved and eluted out of the extraction cell by the high density carbon dioxide. Under these conditions diffusion in the polymer particle is the rate-limiting parameter. Therefore, the recovery does not change with the different supercritical fluid flow rates tested. A distinctly different situation occurs at $80^{\circ} \mathrm{C}$ where diffusion of the solutes in the polymer is relatively fast and components can rapidly diffuse to the polymer surface. If now low flow rates are used, the ability of the extractant to dissolve the solutes and remove them from the extraction cell can become the rate-limiting parameter. This is most likely to occur for components that are present at high concentrations or have high diffusion coefficients in the polymer. In our experiments, the concentrations of Irgafos 168 and Irganox 1076 in polyethylene are much higher than the concentration of Irganox 1010. Moreover, Irgafos 168 and Irganox 1076 have smaller molecular sizes and hence have higher diffusion coeffi- cients. These results indicate that if the ratelimiting parameter is solubility, high supercritical fluid flow rates may be of benefit. Unfortunately, high supercritical fluid flow rates will make the collection of the extracted components from the expanding gas stream more difficult. For this reason, in the following experiments a $50 \mu \mathrm{m}$ fused-silica capillary with a length of $50 \mathrm{~cm}$ was used as the restrictor.

Effects of benzene as a modifier. In addition to the parameters discussed above, the addition of a modifier is another important factor affecting the SFE extraction process. In the present study, the influence of modifiers on the SFE kinetics was investigated using benzene as the modifier. Benzene was selected because of this solvent is known to be a good swelling agent for polyethylene [16]. Figures $7 \mathrm{a}$ and $\mathrm{b}$ illustrate the effects of the modifier on the extraction for Irgafos 168 at 300 bar and $50^{\circ} \mathrm{C}$, and 300 bar and $80^{\circ} \mathrm{C}$, respectively. Similar curves were also found for Irganox 1076 and Irganox 1010. The modifier was spiked onto the polymer sample prior to starting the SFE extraction. With increased modifier amounts added, the extraction yields for each of the three additives increased both at $50^{\circ} \mathrm{C}$ as well as at $80^{\circ} \mathrm{C}$. The magnitude of the increase at 300 bar and $50^{\circ} \mathrm{C}$ was found to be larger than that at 300 bar and $80^{\circ} \mathrm{C}$. The overall extraction yields at $50^{\circ} \mathrm{C}$ and 300 bar with $0.5 \mathrm{~mL}$ benzene as the modifier, however,

Table III. Effects of supercritical fluid flow rate on the SFE extraction recoveries of the three additives in the first $30 \mathrm{~min}$ fraction at $80^{\circ} \mathrm{C}$ and $300 \mathrm{bar}^{a}$

\begin{tabular}{ccccc}
\hline Restrictor & Flow rate $^{\mathrm{b}}$ & $\begin{array}{c}\text { Irganox } 168 \\
(\%)\end{array}$ & $\begin{array}{c}\text { Irganox } 1076 \\
(\%)\end{array}$ & $\begin{array}{c}\text { Irganox } 1010 \\
(\%)\end{array}$ \\
\hline $50 \mu \mathrm{m} \times 50 \mathrm{~cm}$ & $350 \mathrm{~mL} / \mathrm{min}$ & 86.1 & 82.5 & 100.4 \\
$20 \mu \mathrm{m} \times 50 \mathrm{~cm}$ & $70 \mathrm{~mL} / \mathrm{min}$ & 71.5 & 68.9 & 97.4 \\
\hline
\end{tabular}

\footnotetext{
${ }^{\text {a }} \mathrm{SFE}$ extraction recoveries were calculated relative to Soxhlet data.

${ }^{\mathrm{b}}$ Measured as gas flow after expansion.
} 


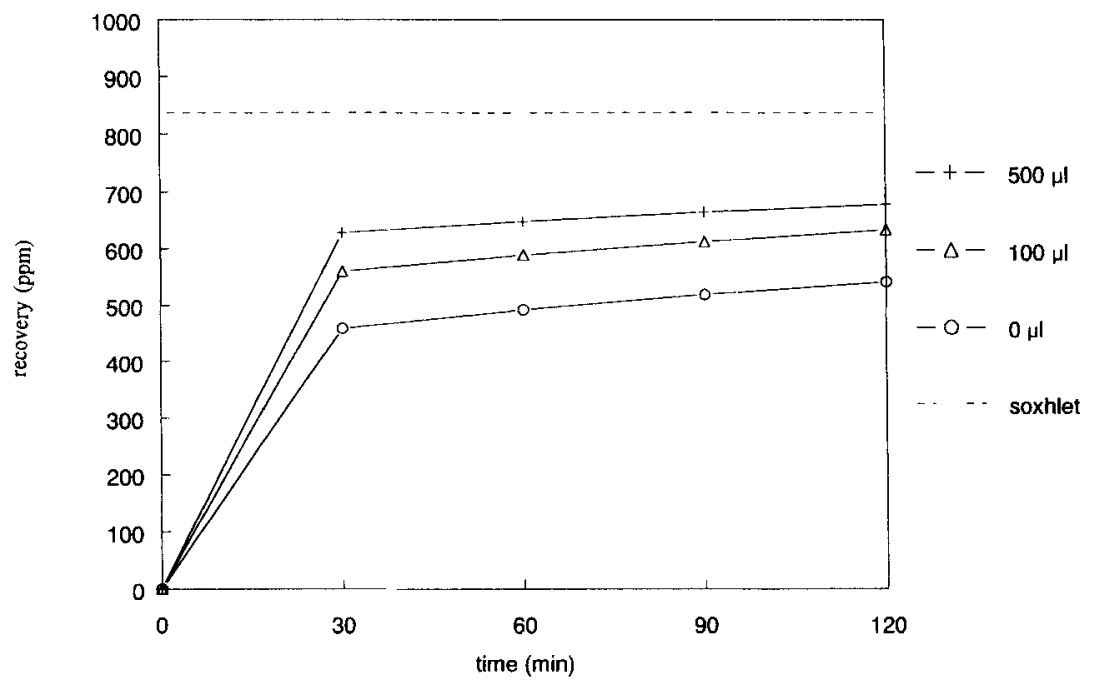

(a)

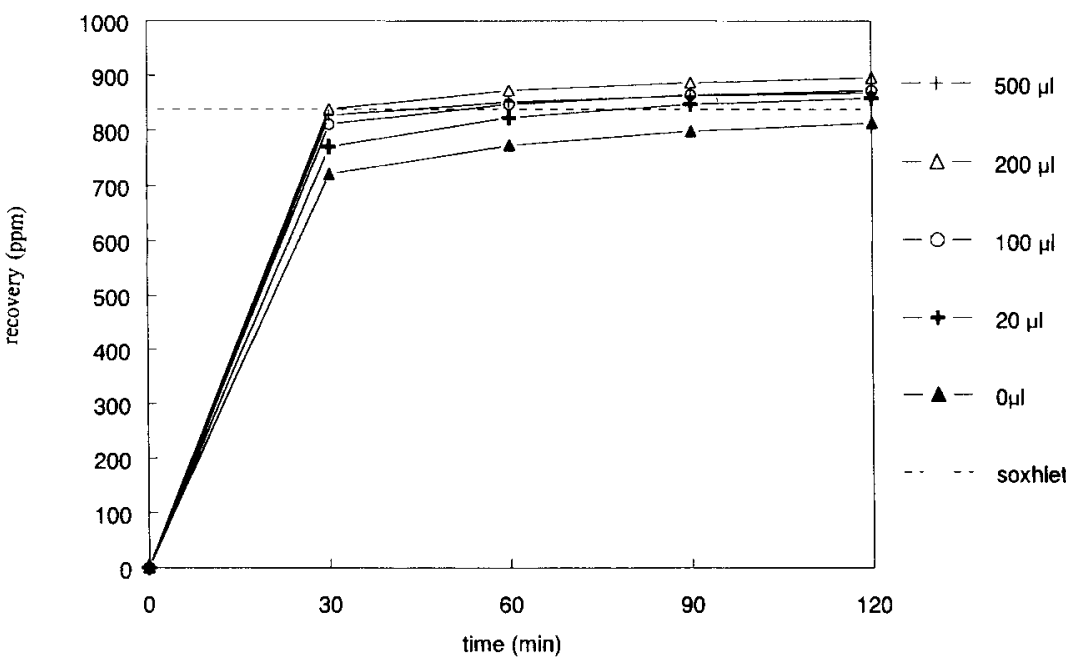

(b)

Figure 7. Effects of modifier amount on SFE extraction rate for Irgafos $168 . \mathrm{A}: 50^{\circ} \mathrm{C}$ and $300 \mathrm{bar}$; $\mathrm{B}$ : $80^{\circ} \mathrm{C}$ and 300 bar. Other details as in Figure 3.

are significant lower than that obtained at $80^{\circ} \mathrm{C}$ and 300 bar with pure carbon dioxide. Modifier amounts larger than $0.5 \mathrm{~mL}$ were not investigated because under these conditions the restrictor was found to block frequently, presumably because a significant fraction of the low molecular weight material was coextracted with the additives. As has been discussed in previous paragraphs, the rate-limiting parameter for extraction at an extraction pressure of 300 bar and extraction temperatures between 50 and $80^{\circ} \mathrm{C}$ is diffusion of the solutes from the core of the polymer particles to the surface. The improvement of the extraction yields observed by the addition of the modifier must hence be due to the fact that the diffusion rates of the solutes increase when the polymer particles swell by the uptake of modifier. The smaller effects of the modifier addition at higher temperatures is most likely due to the fact that diffusion of solutes in the polymer is already relatively fast at higher temperatures. Therefore, modifiers are more effective at lower extraction temperatures.

Modifiers cannot only swell the polymer matrix but also increase the supercritical fluid density and its polarity. If the solubility of the components in the supercritical fluid is not the rate-limiting parameter, the improvement of the SFE recovery upon the addition of a modifier is 


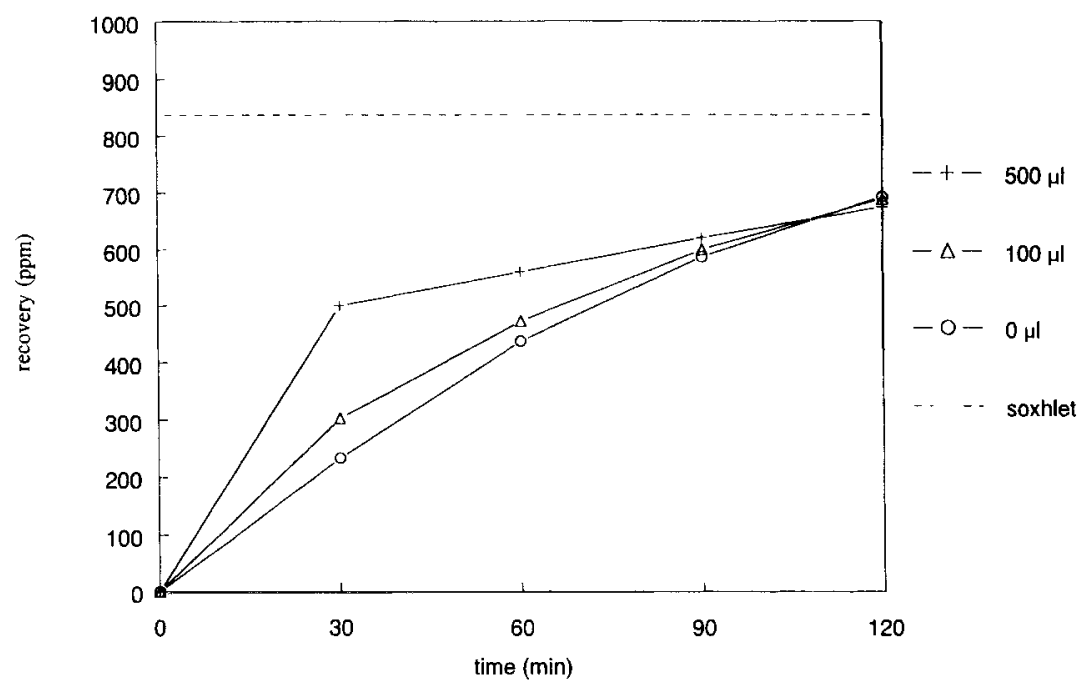

(a)

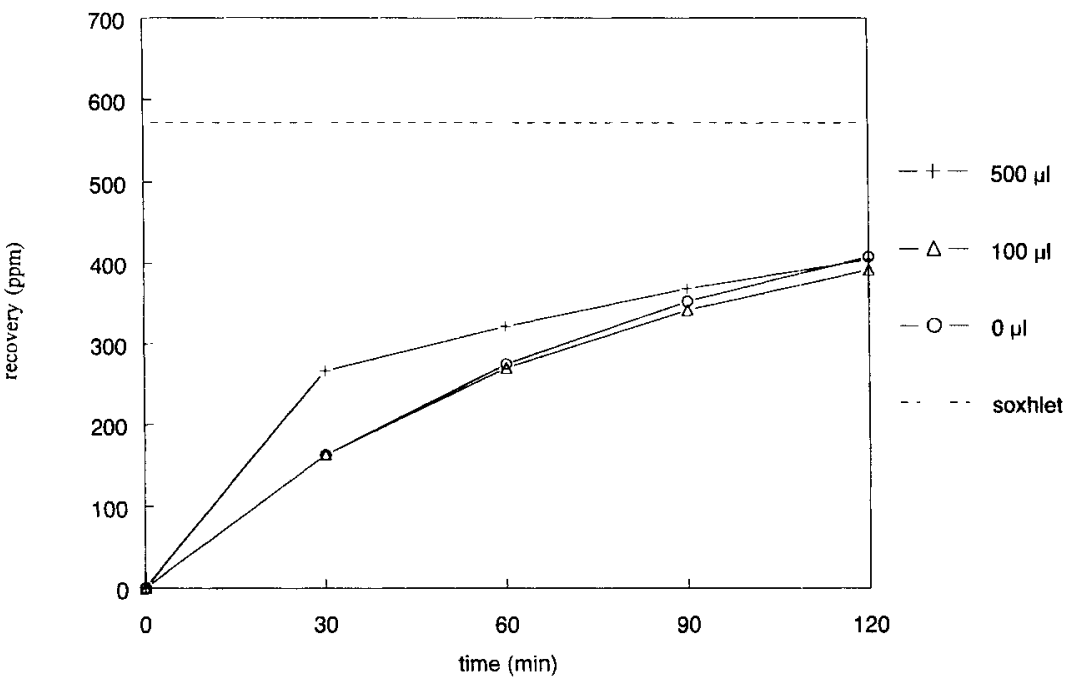

(b)

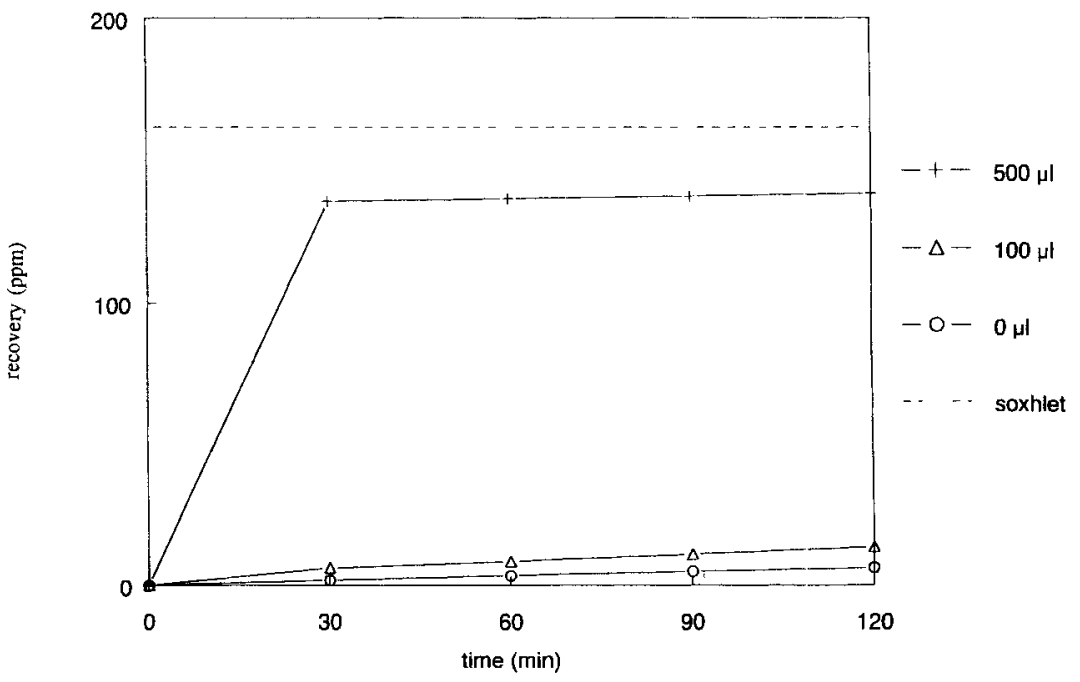

(c)

Figure 8. Effects of modifier amount on SFE extraction rate at $80^{\circ} \mathrm{C}$ and 150 bar. A: Irgafos 168; B: Irganox 1076; C: Irganox 1010. Other details as in Figure 3. 
Table IV. Effects of static time on SFE extraction recoveries in the first 30 min fraction at $50^{\circ} \mathrm{C}$ and 300 bar. $^{\circ}$

\begin{tabular}{cccccc}
\hline & \multicolumn{2}{c}{ Without modifier } & & \multicolumn{2}{c}{ With $0.5 \mathrm{~mL}$ benzene as modifier } \\
\cline { 2 - 3 } \cline { 5 - 6 } Static time & $5 \mathrm{~min}$ & $30 \mathrm{~min}$ & & $5 \mathrm{~min}$ & $30 \mathrm{~min}$ \\
& $(\%)$ & $(\%)$ & & $(\%)$ & $75)$ \\
\hline Irgafos 168 & 52.5 & 54.9 & 58.9 & 70.6 \\
Irganox 1076 & 41.9 & 46.4 & 50.9 & 47.0 \\
Irganox 1010 & 17.9 & 21.2 & 32.8 & \\
\hline
\end{tabular}

${ }^{\text {a }}$ SFE extraction recoveries were calculated relative to Soxhlet data.

mainly due to swelling of the polymer and enhanced diffusion in the swollen polymer. The increase in the solvent strength of the supercritical fluid is, in this case, only of a minor importance. If the solubility of the components in the supercritical fluid is the rate-limiting parameter i.e., at high temperatures and low pressures, the improved solvent strength of the supercritical fluid obtained by the addition of a modifier will increase the SFE extraction rate. Figure 8 shows the effect of the modifier amount added to the extraction cell on the SFE extraction yields at 150 bar and $80^{\circ} \mathrm{C}$. Under these conditions, the extraction rate-limiting parameter when pure carbon dioxide is used is the solubility of the components in the supercritical fluid. It can be seen from this figure that the amount extracted in the first fraction of 30 min increased considerably upon the introduction of the modifier. In particular this is true for Irganox 1010, which has a very low solubility in low density carbon dioxide. It can also be seen that for this solute relatively high modifier concentrations are required. Here again the results for Irgafos 168 and Irganox 1076 are very much similar. Figure 8 also shows, as expected, that the degree of increase is larger at higher modifier concentrations. However, even with $0.5 \mathrm{~mL}$ benzene as modifier, the amount extracted at $80^{\circ} \mathrm{C}$ and 150 bar in the first $30 \mathrm{~min}$ is still less than that extracted at $80^{\circ} \mathrm{C}$ and 300 bar with pure carbon dioxide. Apparently, pure carbon dioxide at $80^{\circ} \mathrm{C}$ and 300 bar is a stronger solvent than carbon dioxide admixed with $0.5 \mathrm{~mL}$ benzene at $80^{\circ} \mathrm{C}$ and 150 bar.

Another important factor affecting the SFE efficiency when a modifier is used is the static time as swelling of polymers is normally a slow process. The effects of the static time on the SFE extraction yields were studied at 300 bar and $50^{\circ} \mathrm{C}$, as well as at 300 bar and $80^{\circ} \mathrm{C}$ using both pure carbon dioxide and carbon dioxide modified with benzene. The results are listed in Tables IV and V, respectively. Variation of the static time from 5 to $30 \mathrm{~min}$ was found to have only a marginal effect on the extraction yields when pure carbon dioxide was used. When a modifier is used, the polymer swells slowly thereby increasing diffusion in the polymer. Now much larger amounts can diffuse into the supercritical fluid at longer static times. The magnitude of the static time effect was found to be larger at lower temperatures because at higher temperatures the polymer is already relatively flexible and diffusion is hence relatively fast.

In the experiments described above, the modifier was directly spiked onto the solid sample in the extraction cell. During the extraction process, the modifier will continuously be removed from the cell by the flow of supercritical fluid. It is evident that the length of time that

Table V. Effects of static time on SFE extraction recoveries in the first 30 min fraction at $80^{\circ} \mathrm{C}$ and 300 bar. $^{a}$

\begin{tabular}{cccccc}
\hline & \multicolumn{2}{c}{ Without modifier } & & \multicolumn{2}{c}{ With 0.5 mL benzene as modifier } \\
\cline { 2 - 3 } Static time & $5 \mathrm{~min}$ & $30 \mathrm{~min}$ & & $5 \mathrm{~min}$ & $30 \mathrm{~min}$ \\
& $(\%)$ & $(\%)$ & & $(\%)$ & $(\%)$ \\
\hline Irafos 168 & 82.2 & 86.1 & & 92.9 & 98.7 \\
Irganox 1076 & 79.7 & 82.5 & & 89.0 & 97.9 \\
Irganox 1010 & 90.5 & 100.4 & & 128.6 & 158.8 \\
\hline
\end{tabular}

${ }^{a}$ SFE extraction recoveries were calculated relative to Soxhlet data. 
the modifier remains in the extraction cell is of importance for the extraction process. A series of experiments was performed to investigate how fast the modifier is removed from the extraction cell. The elution profiles of the modifier were tested by adding $0.5 \mathrm{~mL}$ benzene to the extraction cell packed with a polymer sample already extracted by SFE and monitoring the signal obtained on an FID connected to the outlet of the extraction cell. When helium at 150 bar was used as an inert transporting medium, benzene is retained in the extraction cell for about $60 \mathrm{~min}$ at $80^{\circ} \mathrm{C}$, and about $90 \mathrm{~min}$ at $50^{\circ} \mathrm{C}$. From these results, it is plausible to say that the modifier can penetrate into the polymer or can be adsorbed by the polymer. When supercritical carbon dioxide was pumped through the extraction cell, the modifier was eluted completely within $10 \mathrm{~min}$ under all experimental conditions tested. Apparently the modifier is rapidly extracted by the supercritical carbon dioxide. The rapid elution of modifier also explains why only the amount extracted in the first $30 \mathrm{~min}$ fraction was increased when a modifier was added. The elution profiles of benzene at $80^{\circ} \mathrm{C}$ and 150 bar with helium and carbon dioxide are shown in Figure 9.

From the results shown above, it can be

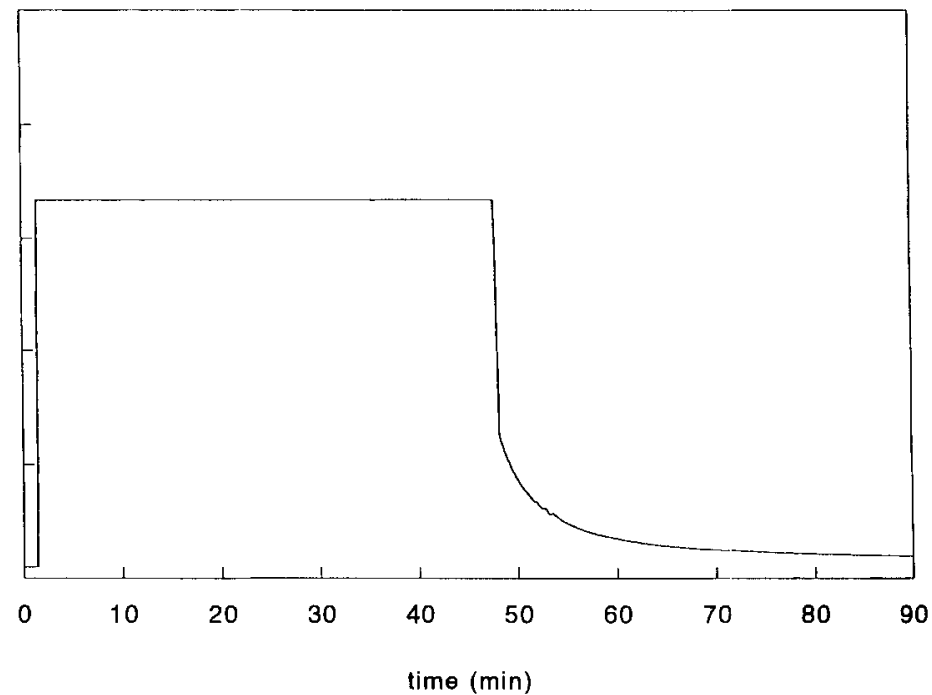

(a)

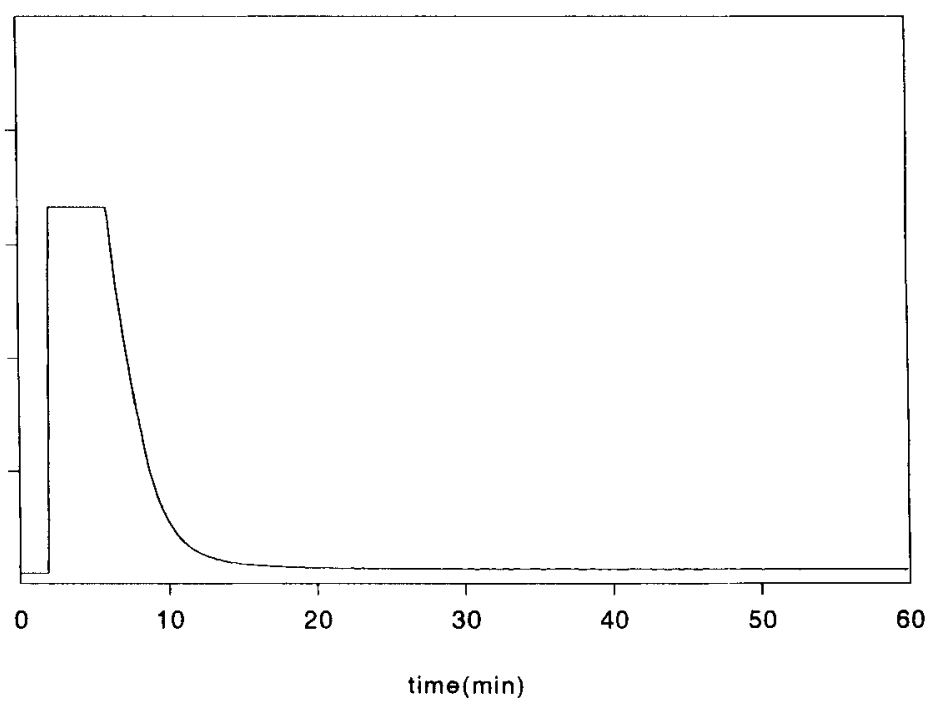

(b)

Figure 9. Elution profile of the modifier with different transporting media at various conditions. A: Helium, $80^{\circ} \mathrm{C}$ and 150 bar; $\mathrm{B}$ : Carbon dioxide, $80^{\circ} \mathrm{C}$ and 150 bar (a static time of 30 min was used prior to the elution). 
Table VI. Comparison of extraction yields $(\mathrm{ppm})$ in the first 30 min fraction at $80^{\circ} \mathrm{C}$.

\begin{tabular}{lcccc}
\hline & $\mathrm{CO}_{2}(150 \mathrm{bar})+$ & & $\mathrm{CO}_{2}(70 \mathrm{bar})+$ & $\mathrm{He}(150 \mathrm{bar})+$ \\
& $0.5 \mathrm{~mL} \mathrm{C}_{6} \mathrm{H}_{6}$ & $\mathrm{CO}_{2}(150 \mathrm{bar})$ & $0.5 \mathrm{~mL} \mathrm{C}_{6} \mathrm{H}_{6}$ & $0.5 \mathrm{~mL} \mathrm{C}_{6} \mathrm{H}_{6}$ \\
\hline Irgafos 168 & 499.3 & 233.3 & 45.1 & 66.6 \\
Irganox 1076 & 266.5 & 162 & 9.0 & 12.2 \\
Irganox 1010 & 136.1 & 1.7 & 3.2 & 4.2 \\
\hline
\end{tabular}

seen that the main effects of modifier in the SFE extraction of polymeric materials are related to increasing the diffusion coefficients of the solutes in the polymer, presumably due to swelling of the polymer particles, and to the improvement of the solvent strength of the supercritical fluid. In the extraction of environmental samples, the modifier is used mainly for the deactivation of active sites on the surface and only small amounts of modifier can have a drastic effect on the extraction process [17]. As discussed above, a much larger amount of modifier is needed in the extraction of polymeric materials. This is especially the case at low temperatures where the modifier mechanism actually involves swelling of the polymer resulting in increased diffusion coefficients for the solutes.

In order to investigate the modifier role in the SFE extraction in more detail, the polymer additives were extracted with modifier using either pure helium $\left(150\right.$ bar and $\left.80^{\circ} \mathrm{C}\right)$ or pure carbon dioxide $\left(70\right.$ bar and $80^{\circ} \mathrm{C}$ ) as the carrier medium. No extraction occurred under these conditions without modifier. It is interesting to see that the amount extracted at $80^{\circ} \mathrm{C}$ and 150 bar with carbon dioxide admixed with $0.5 \mathrm{~mL}$ benzene is much larger than the sum of the amounts extracted under the same conditions without a modifier and the amount extracted with $0.5 \mathrm{~mL}$ benzene using either helium (150 bar and $\left.80^{\circ} \mathrm{C}\right)$ or carbon dioxide $(70$ bar and $80^{\circ} \mathrm{C}$ ) as the carrier medium (Table VI). From this it can be concluded that the extraction rate is not simply the addition of the extraction rates with only modifier and pure carbon dioxide.

\section{REFERENCES}

1. F.W. Billmeyer, Textbook of Polymer Science (Wiley, New York, 1984), p. 3.
2. V. Camel, A. Tambute and M. Caude, J. Chromatogr. 642, 293 (1993).

3. D.R. Gere, C.R. Knipe, P. Castelli, J. Hendrich, L.G. Randall, H. Schulenberg-Schell, R. Schuster, L. Doherty, J. Orolin, and H.B. Lee, J. Chromatogr. Sci. 31, 246 (1993).

4. X. Lou, H.-G. Janssen, and C.A. Cramers, HRC \& CC, 16, 425 (1993).

5. R.J. Houben, H.-G.M. Janssen, P.A. Leclercq, J.A. Rijks, and C.A. Cramers, J. High Resolut. Chromatogr./Chromatogr. Commun. 13, 669 (1990).

6. Analytical Supercritical Fluid Chromatography and Extraction, M.L. Lee and K.E. Markides, Eds. (Chromatography Conference, Provo, Ut, 1990).

7. K.D. Bartle, T. Boddington, A.A. Clifford, and N.J. Cotton, Anal. Chem. 63, 2371 (1991).

8. T.L. Chester, J.D. Pinkston, and D.E. Raynle, Anal. Chem. 66, 106R (1994).

9. K.D. Bartle, A.A. Clifford, S.B. Hawthorne, J.J. Langenfeld, D.J. Miller, and R.J. Robinson, J. Supercrit. Fluids 3, 143 (1990).

10. N.J. Cotton, K.D. Bartle, A.A. Clifford, and C.J. Dowle, J. Chromatogr. Sci. 31, 157 (1993).

11. S. Kueppers, Chromatographia 33, 434 (1992).

12. A. Venema, H.J.M.F. van de Ven, F. David, and P. Sandra, J. High Resolut. Chromatogr./Chromatogr. Commun. 16, 522 (1993).

13. W.G. Whitman, Chem. Metall. Eng. 29, 147 (1923).

14. I. Goodman and B.F. Nesbit, J. Polym. Sci. 48, 423 (1960).

15. J.S. Verentas, J. Appl. Polym. Sci. 25, 1297 (1980).

16. R.A. Orwoll, in Encyclopedia of Polymer Science and Engineering, H.F. Mark, N.M. Bikales, C.G. Overberger, G. Menges, and J.I. Kroschwitz, Eds. (Wiley, New York), Vol. 15, p. 231.

17. J.J. Langenfeld, S.B. Hawthorne, D.J. Miller, and J. Pawliszyn, Anal. Chem. 66, 909 (1994).

Received: February 14, 1995 Accepted: April 17, 1995 